УДК 373.5(4):008-022.218:004

Іванюк Ірина Володимирівна

науковий співробітник відділу компаративістики інформаційно-освітніх інновацій Інститут інформаційних технологій і засобів навчання НАПН України, м. Київ, Україна iivanyuk@yandex.ru

\title{
ПЕДАГОГІЧНИЙ ЕКСПЕРИМЕНТ ЩОДО СФОРМОВАНОСТІ ПОЛІКУЛЬТУРНОЇ КОМПЕТЕНТНОСТІ УЧНЯ В УМОВАХ КОМП'ЮТЕРНО ОРІЄНТОВАНОГО НАВЧАЛЬНОГО СЕРЕДОВИЩА
}

\begin{abstract}
Анотація. У статті представлені результати експериментальної перевірки рівнів сформованості полікультурної компетентності учнів загальноосвітніх навчальних закладів в умовах комп'ютерно орієнтованого навчального середовища. Визначено критерії для оцінювання рівня сформованості полікультурної компетентності учнів у комп'ютерно орієнтованому навчальному середовищі. Зроблено висновок, що проведений педагогічний експеримент підтвердив робочу гіпотезу дослідження: підвищення рівня сформованості полікультурної компетентності учнів у комп'ютерно орієнтованому навчальному середовищі може бути досягнуто через педагогічно доцільне і науково-обгрунтоване застосування змісту, форм та засобів комп'ютерно орієнтованого навчального середовища в умовах полікультурної освіти в навчально-виховному процесі.
\end{abstract}

Ключові слова: полікультурна компетентність; комп'ютерно орієнтоване навчальне середовище; педагогічний експеримент.

\section{1. ВСТУП}

Розвиток інформаційно-комунікаційних технологій (IКТ) у європейському освітньому просторі, орієнтація освіти на надання вільного і рівного доступу до освітніх ресурсів актуалізує проблему створення нових можливостей для шкільного навчання через комп'ютерно орієнтовані навчальні середовища (КОНС), де учні можуть повністю реалізувати свій потенціал, формувати життєво важливі й необхідні якості для їх становлення як успішних громадян демократичного полікультурного європейського суспільства. Перетинання i взаємозв'язок різних культур у інформаційному суспільстві відбувається нині у швидких та інтенсивних темпах завдяки IКТ. Спілкуючись у віртуальному просторі, учні й учителі мають багато можливостей щодо виявлення власної культури спілкування, подання відомостей i даних, створення і презентації навчальних ресурсів. Таке поєднання потреб учнів 3 навчальними цілями, які ставить система освіти щодо формування їхнього полікультурного світогляду, вимагає використовувати можливості навчального середовища, у тому числі відповідних засобів і можливостей сучасних IКТ.

Постановка проблеми. Важливим елементом дисертаційного дослідження «Розвиток комп'ютерно орієнтованого навчального середовища в умовах полікультурної освіти учнів в країнах Свропейського Союзу» $є$ експериментальна перевірка ефективності моделі комп'ютерно орієнтованого навчального середовища в шкільній практиці у формуванні полікультурної компетентності учнів [1]. Робочою гіпотезою дослідження є твердження: підвищення рівня сформованості полікультурної компетентності учнів у комп'ютерно орієнтованому навчальному середовищі може бути досягнуто через педагогічно доцільне і науково-обгрунтоване застосування змісту, форм та засобів комп'ютерно орієнтованого навчального середовища в умовах полікультурної освіти в навчально-виховному процесі.

Аналіз останніх досліджень і публікацій. Полікультурна компетентність як 
науково-педагогічна проблема розглядається вітчизняними науковцями Л. І. Воротняк, Л. А. Гончаренко, В. В. Кузьменко, О. І. Пометун, М. В. Сімоненко та ін.; зарубіжними дослідниками Н. Девіс, Г. Макалістер, М. Ракотомена, Е. Тейлор, А. Томас, А. Фантіні та ін.

Практика створення й упровадження комп'ютерно орієнтованого навчального середовища аналізувалася в роботах В. Ю. Бикова, М. І. Жалдака, Ю. О. Жука, В. І. Клочко, В. В. Лапинського, Н. В. Морзе, О. В. Співаковського, Ю. В. Тріпса та ін. На нашу думку, недостатньо уваги в сучасних наукових роботах приділяється проблемі формування полікультурної компетентності учнів в умовах комп'ютерно орієнтованого навчального середовища.

Мета статті - представити результати експериментальної перевірки рівнів сформованості полікультурної компетентності учнів загальноосвітніх навчальних закладів в умовах комп'ютерно орієнтованого навчального середовища, яка проводилась автором у рамках дисертаційного дослідження «Розвиток комп'ютерно орієнтованого навчального середовища в умовах полікультурної освіти учнів у країнах Свропейського Союзу».

\section{2. ТЕОРЕТИЧНІ ОСНОВИ ДОСЛІДЖЕННЯ}

Уточнимо зміст основних понять «полікультурна компетентність учня» i «комп'ютерно орієнтоване навчальне середовище в умовах полікультурної освіти учнів».

У зарубіжній науково-дослідній літературі існує декілька визначень полікультурної компетентності. А. Томас вважає, що полікультурна компетентність проявляється у здатності визнавати, поважати, цінити та продуктивно використовувати у власній та інших культурних умовах сприйняття, судження, відчуття та дії з метою створення взаємної адаптації, толерантності до несумісності, розвитку форм співпраці [2, с. 143]. Це визначення підкреслює важливість формування полікультурної компетентності в кожної людини. Воно звертає увагу на здатність особистості бути гнучким у власній поведінці залежно від ситуації і контексту.

Дослідники Інституту інтеркультурної дидактики (Німеччина), вважають, що полікультурна компетентність має три складові: знання (когнітивні аспекти), що включають в себе знання мов, знання про культуру країни, про культурний вимір/ культурні стандарти/культурні процеси, знання про етноцентризм, знання процесів міграції й інтеграції, специфічні знання про культуру і концепції культури; здібності (емоційні/афективні аспекти), які включають до свого списку спостереження, обізнаність, правильне розуміння ситуації, адекватність, саморефлексію, сприйняття іноземного світогляду, здатність змінювати свої погляди на майбутнє, здатність до співчуття, гнучкість, відкритість, толерантність, чутливість; навички (аспекти поведінки), які передбачають володіння стрес менеджментом, управління конфліктами, навички комунікації, уміння змінюватись, здатність інтегруватись в інше культурне середовище, уміння вирішувати критичні ситуації, невимушене спілкування, стратегії роботи з культурним шоком [3].

Дослідження українських науковців також свідчать про різні підходи щодо визначення поняття «полікультурної компетентності». Дослідники Л. А. Гончаренко та В. В. Кузьменко розглядають полікультурну компетентність як здатність особистості жити й діяти в багатокультурному суспільстві [4, с. 91].

Л. І. Воротняк визначає полікультурну компетентність як здатність людини інтегруватися в іншу культуру за збереження взаємозв'язку з рідною мовою, культурою, яка грунтується на поєднанні особистісних якостей, синтезованих знаннях, 
уміннях і навичках позитивної міжетнічної й міжкультурної взаємодії, що в результаті сприяє безконфліктній ідентифікації особистості в багатокультурному суспільстві та їі інтеграції в полікультурний світовий простір [5, с. 106].

М. В. Сімоненко пропонує розглядати полікультурну компетентність майбутнього вчителя як інтегративна якість особистості майбутнього фахівця, що формується в процесі навчання, і включає систему полікультурних знань, умінь, навичок, інтересів, потреб, мотивів, цінностей, полікультурних якостей, досвіду, соціальних норм і правил поведінки, необхідних для повсякденного життя й діяльності в сучасному полікультурному суспільстві, що реалізується в здатності ефективно розв'язувати завдання педагогічної діяльності в ході позитивної взаємодії із суб єктами освітнього процесу - представниками різних культур [6].

Так, відповідно до зробленого вище аналізу, ми пропонуємо розглядати полікультурну компетентність учня як сукупність знань 3 культур інших національностей i віросповідань, здатності й уміння змінювати своє ставлення, відносини і поведінку так, щоб бути відкритим і гнучким до інших культур на практиці, готовність до толерантної і дружньої взаємодії з представниками різних культур i релігій.

Важливим постає завдання щодо створення такого комп'ютерно орієнтованого навчального середовища, яке б задовольняло вимоги до полікультурної освіти молоді в умовах інформаційного суспільства.

С. О. Сисоєва розглядає «комп'ютерно навчально-розвивальне середовище» 3 точки зору дистанційної освіти і визначає як «дидактичну модель конкретної предметної галузі, сконструйовану за допомогою комп'ютерних засобів, інтегровану в єдиний інформаційно-освітній простір і спрямовану на педагогічну і психологічну підтримку процесу оволодіння знаннями, уміннями й навичками з певного предмета, а також розвиток мотивації до навчання, провідних якостей особистості, які забезпечують іï здатність до постійного (протягом життя) самовдосконалення i саморозвитку» [7, с. 83-84].

Ю. О. Жук трактує «комп'ютерно орієнтоване навчальне середовище» як «особистісно-орієнтоване навчальне середовище, у складі якого присутні, у міру необхідності, апаратно-програмні засоби інформаційно-комунікаційних технологій» [8].

Зарубіжними дослідниками формування полікультурної компетентності в КОНС розглядається в різних аспектах. З. Абрамс звертає увагу на подолання культурних стереотипів і формування полікультурної компетентності через участь в Інтернет проектах. Дослідники Дж. Белз, М. Бирам, М. Ліау, Дж. Фурстенберг та ін. вважають, що полікультурна компетентність формується під час вивчення іноземних мов он-лайн. Використання ІКТ для формування полікультурної компетентності під час підготовки вчителів і керівників ЗНЗ розглядають у своїх роботах Н. Девіс, А. Браун і Р. Фердіг, І. Гібсон і Дж. Шіллер та ін.

Отже, на нашу думку, комп'ютерно орієнтоване навчальне середовище в умовах полікультурної освіти - це середовище, що базується на інформаційно-комунікаційних технологіях, освітніх ресурсах і сервісах інформаційно-комунікаційних мереж, що забезпечують навчання, діяльність та підтримку полікультурного розвитку особистості через участь у міжнародних проектах, віртуальних навчальних спільнотах, вивчення іноземних мов у контексті полікультурної освіти.

Спираючись на вищеозначені позиції, нами була розроблена модель КОНС розвитку полікультурної компетентності учня [1]. За основу моделі було взято ствердження В. Ю. Бикова, що навчальне середовище навчального закладу відображає людиноцентристську освітню парадигму, в центрі навчального середовища знаходиться 
учень, заради якого навчальне середовище створюється, існує та розвивається [9, с. 378].

Для організації навчального процесу і змістового наповнення навчальних програм ми орієнтувались і використовували такі основні теорії навчання, які відповідають завданням полікультурної освіти в умовах КОНС: біхевіористична, гуманістична, асоціативно-рефлекторна, проблемного навчання та ін. Виходячи з зазначених теорій, нами були виокремлені наукові підходи: системний, компетентнісний, культурологічний, гендерний, особистісно-орієнтований, діяльнісний, міжпредметний. Згідно з вищезазначеними підходами, у нашому дослідженні до процесу полікультурної освіти учнів ми пропонуємо застосовувати наступні принципи навчання: культуровідповідності, культурної ідентичності, рівного доступу до освіти, принцип антидискримінації, інформаційної безпеки, мобільності, інтерактивності [1].

\section{3. РЕЗУЛЬТАТИ ДОСЛІДЖЕННЯ}

Експериментальна перевірка рівня сформованості полікультурної компетентності учнів в умовах комп'ютерно орієнтованого навчального середовища проводилась у два етапи (констатувальному і формувальному) впродовж 2013-2015 pр. через здійснення педагогічного експерименту. Ми керувались підходами дослідника С. У. Гончаренка, який розуміє педагогічний експеримент як спеціальне внесення в педагогічний процес принципово важливих змін відповідно до завдань дослідження й гіпотези; така організація процесу, яка дає можливість бачити зв'язки між досліджуваними явищами без порушення його цілісності; глибокий якісний аналіз та якомога точніше кількісне вимірювання як внесених у педагогічний процес змін, так і результатів усього процесу [10]. Під час проведення нашого педагогічного експерименту ми погоджуємося 3 позицією дослідника щодо складності оцінювання результатів навчально-виховних впливів, де необхідно оцінити ставлення учнів. А тому інструментарій педагогічного експерименту носить характер безоціночних суджень, які пов'язані 3 ціннісними характеристиками і рисами особистості.

Під час проведення експериментальної роботи було здійснено такі завдання:

- аналіз вхідного рівня сформованості полікультурної компетентності учнів у комп'ютерно орієнтованому навчальному середовищі, коригування тематики уроків і заходів, спрямованих на формування знань, умінь, навичок та компетентностей учнів у сфері культурного різноманіття на цій основі 3 урахуванням досвіду країн Свропи;

- планування і реалізацію заходів (проведення уроків, навчально-виховних заходів, семінарів для вчителів і методистів) на основі впровадження методичних рекомендацій «Використання електронних освітніх ресурсів комп'ютерно орієнтованого навчального середовища в умовах полікультурної освіти учнів» [11] (17 навчальних годин), що здійснювалися у загальноосвітніх навчальних закладах Київської, Черкаської, Рівненської, Полтавської, Львівської областей і м. Києва та в системі післядипломної педагогічної освіти;

- зіставлення результатів контрольної й експериментальної груп для визначення динаміки стану сформованості полікультурної компетентності учнів у комп'ютерно орієнтованому навчальному середовищі;

- розробка перспектив і рекомендацій на основі перевірки ефективності моделі комп'ютерно орієнтованого навчального середовища в умовах полікультурної освіти учнів з урахуванням європейських підходів.

Організація ходу експериментальної діяльності та створення опитувальних листів 
(анкет) для учнів і вчителів, проведення експерименту, аналіз його результатів здійснювалися відповідно до основних положень математичної статистики, що наведені у працях Б. С. Гершунського [12], О. В. Сидоренко [13] та Р. А. Фішера [14].

Експериментальне дослідження здійснювалось на базі таких закладів: приватного ЗНЗ «Київського ліцею бізнесу» (м. Київ), ЗНЗ «Першої міської гімназії м. Черкаси» (м. Черкаси, Черкаська обл.), спеціалізованої школи-дитсадка «Лісова казка» 3 поглибленим вивченням іноземних мов (м. Київ), приватного ЗНЗ гімназії «Апогей» (м. Київ), приватного ЗНЗ гуманітарної гімназії «Гармонія» (м. Київ), Семиполківського НВК «ЗОШ I-III ступені - ДНЗ» (с. Семиполки, Броварський район Київської області), спеціалізованої школи ім. Івана Кудрі №181 (м. Київ), Княжицької загальноосвітньої школи I-II ступенів (с. Княжичі, Києво-Святошинський район Київської області), ВНЗ Університету економіки і права «КРОК» (м. Київ), Полтавського обласного інституту післядипломної педагогічної освіти імені M. В. Остроградського (м. Полтава, Полтавська обл.), Рівненського обласного інституту післядипломної педагогічної освіти (м. Рівне, Рівненська обл.), Львівського обласного інституту післядипломної педагогічної освіти (м. Львів, Львівська обл.), Центрального інституту післядипломної педагогічної освіти (м. Київ).

Протягом констатувального етапу (2013-2014рр.) експериментальної перевірки моделі КОНС в умовах полікультурної освіти учнів було визначено гіпотезу дослідження; проведено опитування учнів ЗНЗ і визначено їх рівень сформованості полікультурної компетентності та рівень володіння ІКТ; обгрунтовано зміст, форми, методи і засоби формування полікультурної компетентності учнів в умовах КОНС; розроблено модель КОНС для формування полікультурної компетентності учня; розроблено методичні рекомендації для вчителів. Слід наголосити, що вимірювання рівня сформованості полікультурної компетентності учнів, які здійснювали педагогічно спрямоване навчання і діяльність у КОНС, стало одним з основних чинників перевірки запропонованої моделі.

Оцінка стану сформованості полікультурної компетентності учнів здійснювалась протягом 2012/2013 навчального року шляхом проведення анкетування учнів. В опитуванні взяло участь 300 учнів, 60 \% з яких - 8-й клас, інші 40\% - 9-й клас.

На формувальному етапі (2014-2015 рр.) педагогічного експерименту проведено низку навчально-виховних заходів на основі методичних рекомендацій (семінари для вчителів й учнів, виховні години для учнів); експериментальну перевірку рівнів сформованості полікультурної компетентності учнів ЗНЗ в умовах КОНС через анкетування; систематизовано й узагальнено результати. До участі у формувальному етапі експерименту було залучено 300 учнів 9-10-х класів. Контрольна група (КГ) складалась 3 134-х осіб; експериментальна група (ЕГ) - $з$ 166-х осіб.

Анкета для учнів включала 20 запитань за трьома блоками - змістовим, поведінковим і використання ІКТ-КОНС. Вона була розроблена на основі аналізу Міжкультурного індексу чутливості (англ., the Intercultural Sensitivity Index) [15] та анкети для вимірювання рівня демократичної громадянськості й полікультурної компетентності, які розробляються департаментом освіти Ради Європи [16]. В основу формування критеріїв для оцінювання демократичної громадянськості й полікультурної компетентності експерти Ради Свропи включили чотири компоненти: володіння цінностями, формування позицій, навичок, набуття знань і критичне розуміння. Вони включають в себе: цінності: уміння цінити інших людей, людську гідність і права людини; уміння цінити культурну різноманітність і відмінності культури інших людей; уміння цінити демократію, правосуддя, справедливість, рівноправність і верховенство права; позиції: відкритість до культурних особливостей інших людей, до різних віросповідань; повага і толерантність до інших людей, до 
різних віросповідань; усвідомлення своєї громадянської позиції; відповідальність; готовність до самореалізації; навички: самостійного навчання; аналітичного й критичного мислення; уміння слухати і спостерігати; емпатії; гнучкості та адаптації; мовні та комунікаційні навички; навички співпраці; навички вирішувати конфлікти; знання $i$ критичне розуміння самого себе; різних мов; світу (включаючи, політику, права людини, різні культури, віросповідання, історію, економіку, ЗМІ, навколишнього середовища та ін.) [16].

Ми визначили такі критерії для оцінювання сформованості полікультурної компетентності учня в умовах КОНС: когнітивний (знання), поведінковий (відношення, цінності), практичний (взаємодія з представниками різних культур з використанням IКТ). По кожному з критеріїв були визначено три рівні сформованості полікультурної компетентності учня: низький, середній, високий (табл. 1).

Таблиця 1

\section{Таблиця критеріїв і рівнів оцінювання сформованості полікультурної компетентності учня в умовах КОНС}

\begin{tabular}{|c|c|c|c|}
\hline № & Критерій & Рівні & $\begin{array}{c}\% \text { рівня } \\
\text { сформовано } \\
\text { сті }\end{array}$ \\
\hline \multirow[t]{3}{*}{1.} & \multirow{3}{*}{$\begin{array}{l}\text { Когнітивний (знання) - } \\
\text { усвідомлення культурного } \\
\text { різноманіття світу; знання } \\
\text { таких понять, як «культура», } \\
\text { «полікультурне } \\
\text { суспільство»; потреба в } \\
\text { набутті нових знань щодо } \\
\text { багатокультурності світу, } \\
\text { особливостей } \\
\text { інших культур }\end{array}$} & $\begin{array}{l}\text { Високий - учень усвідомлює культурне } \\
\text { різноманіття світу; знає, що означають поняття } \\
\text { «культура», «полікультурне суспільство»; має } \\
\text { потребу в набутті нових знань щодо } \\
\text { багатокультурності світу, особливостей розвитку } \\
\text { iнших культур }\end{array}$ & $75-100 \%$ \\
\hline & & $\begin{array}{l}\text { Середній - учень не повною мірою усвідомлює } \\
\text { культурне різноманіття світу; не впевнено розуміє, } \\
\text { що означають поняття «культура», «полікультурне } \\
\text { суспільство»; має слабо виражену потребу в } \\
\text { набутті нових знань щодо багатокультурності світу, } \\
\text { особливостей розвитку інших культур }\end{array}$ & $40-74 \%$ \\
\hline & & $\begin{array}{l}\text { Низький - учень не усвідомлює культурне } \\
\text { різноманіття світу; не знає, що означають поняття } \\
\text { «культура», «полікультурне суспільство»; не має } \\
\text { потреби в набутті нових знань щодо } \\
\text { багатокультурності світу, особливостей розвитку } \\
\text { інших культур }\end{array}$ & $0-39 \%$ \\
\hline \multirow[t]{2}{*}{2.} & \multirow{2}{*}{ 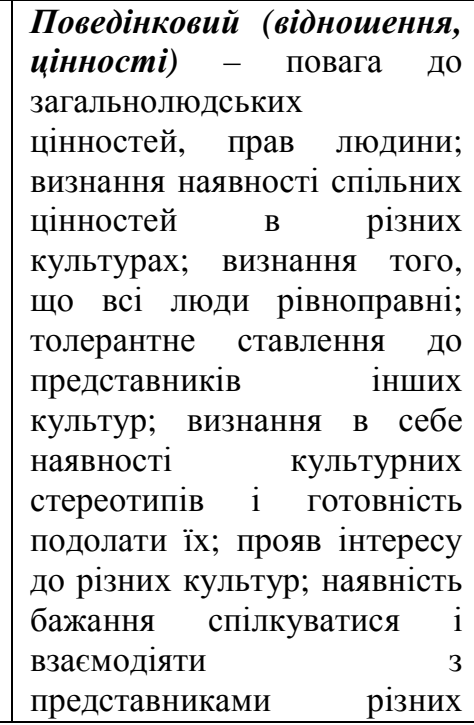 } & $\begin{array}{l}\text { Високий - учень поважає загальнолюдські } \\
\text { цінності; визнає наявність спільних цінностей в } \\
\text { різних культурах; визнає, що всі люди } \\
\text { рівноправні,незалежно від їхьої статі, раси, } \\
\text { національності, віку, соціального походження та } \\
\text { релігійних уподобань; толерантно ставиться до } \\
\text { представників інших культур; визнає в себе } \\
\text { наявність культурних стереотипів і готовність } \\
\text { подолати іх; проявляє інтерес до різних культур; } \\
\text { має бажання спілкуватися і взаємодіяти з } \\
\text { представниками різних культур; вважає, що } \\
\text { розвивається як особистість, спілкуючись з } \\
\text { представниками різних культур }\end{array}$ & $75-100 \%$ \\
\hline & & $\begin{array}{l}\text { Середній - учень не достатньо поважає } \\
\text { загальнолюдські цінності; не впевнений щодо } \\
\text { наявності спільних цінностей в різних культурах; } \\
\text { не впевнений, що всі люди рівноправні,незалежно } \\
\text { від їхньої статі, раси, національності, віку, }\end{array}$ & $40-74 \%$ \\
\hline
\end{tabular}




\begin{tabular}{|c|c|c|c|}
\hline & \multirow[t]{2}{*}{$\begin{array}{l}\text { культур; ставлення до } \\
\text { культурного різноманіття як } \\
\text { до джерела } \\
\text { особистості }\end{array}$} & $\begin{array}{l}\text { соціального походження та релігійних уподобань; } \\
\text { не достатньо толерантно ставиться до } \\
\text { представників інших культур; не впевнений, що } \\
\text { має культурні стереотипи; не проявляє достатнього } \\
\text { інтересу до різних культур; не впевнений, що хоче } \\
\text { спілкуватися і взаємодіяти з представниками різних } \\
\text { культур; не впевнений, що розвивається як } \\
\text { особистість, спілкуючись з представниками різних } \\
\text { культур }\end{array}$ & \multirow[b]{2}{*}{$0-39 \%$} \\
\hline & & $\begin{array}{l}\text { Низький - учень не поважає загальнолюдські } \\
\text { цінності; не визнає наявність спільних цінностей в } \\
\text { різних культурах; не визнає, що всі люди } \\
\text { рівноправні,незалежно від іхньої статі, раси, } \\
\text { національності, віку, соціального походження та } \\
\text { релігійних уподобань; не толерантно ставиться до } \\
\text { представників інших культур; не визнає в себе } \\
\text { наявність культурних стереотипів і готовність } \\
\text { подолати іх; не проявляє інтерес до різних культур; } \\
\text { не має бажання спілкуватися і взаємодіяти з } \\
\text { представниками різних культур; не вважає, що } \\
\text { розвивається як особистість, спілкуючись } 3 \\
\text { представниками різних культур }\end{array}$ & \\
\hline \multirow[t]{3}{*}{3.} & \multirow{3}{*}{$\begin{array}{l}\text { Практичний } \\
\text { представниками }\end{array}$} & $\begin{array}{l}\text { Високий - учень використовує комп’ютерні засоби } \\
\text { навчання під час підготовки до уроків та у свій } \\
\text { вільний час; вважає комп’ютерні засоби навчання } \\
\text { ефективним інструментом для отримання знань про } \\
\text { інші культури; вважає, що використання мережі } \\
\text { Інтернет, спілкування у віртуальних спільнотах } \\
\text { допомагає отримати знання про різні культури; має } \\
\text { друзів серед представників інших } \\
\text { культур/національностей/країн і спілкується з } \\
\text { ними, зокрема, через Інтернет; бере участь у } \\
\text { міжнародних он-лайн проектах }\end{array}$ & $75-100 \%$ \\
\hline & & $\begin{array}{l}\text { Середній - учень рідко використовує комп’ютерні } \\
\text { засоби навчання під час підготовки до уроків та у } \\
\text { свій вільний час; не впевнений, що комп’ютерні } \\
\text { засоби навчання є ефективним інструментом для } \\
\text { отримання знань про інші культури; не впевнений, } \\
\text { що використання мережі Інтернет, спілкування у } \\
\text { віртуальних спільнотах допомагає отримати знання } \\
\text { про різні культури; не впевнений, що має друзів } \\
\text { серед } \\
\text { культур/національностей/країн, щоб спілкуватися з } \\
\text { ними через Інтернет; не впевнений, що хоче брати } \\
\text { участь у міжнародних он-лайн проектах }\end{array}$ & $40-74 \%$ \\
\hline & & $\begin{array}{l}\text { Низький - учень не використовує комп’ютерні } \\
\text { засоби навчання під час підготовки до уроків та у } \\
\text { свій вільний час; не вважає комп’ютерні засоби } \\
\text { навчання ефективним інструментом для отримання } \\
\text { знань про інші культури; не вважає, що } \\
\text { використання мережі Інтернет, спілкування у } \\
\text { віртуальних спільнотах допомагає отримати знання } \\
\begin{array}{l}\text { про різні культури; не має друзів серед } \\
\text { представників } \\
\text { культур/національностей/країн; не бере участь у } \\
\text { міжнародних он-лайн проектах }\end{array}\end{array}$ & $0-39 \%$ \\
\hline
\end{tabular}




\section{Загальні оцінки сформованості полікультурної компетентності учнів на початку експерименту за змістовим блоком}

\begin{tabular}{|c|c|c|c|c|c|c|c|c|}
\hline \multirow{3}{*}{$\begin{array}{c}\text { № п/п } \\
\text { питання }\end{array}$} & \multicolumn{6}{|c|}{ Початок експерименту (IЕ) } & \multicolumn{2}{|c|}{$\begin{array}{c}\text { Кількість } \\
\text { (чол.) }\end{array}$} \\
\hline & \multicolumn{2}{|c|}{ Tak } & \multicolumn{2}{|c|}{ Не впевнен } & \multicolumn{2}{|c|}{$\mathbf{H i}$} & 134 & 166 \\
\hline & $\mathbf{K \Gamma}$ & EГ & $\mathbf{K} \Gamma$ & $\mathbf{E} \Gamma$ & $\mathbf{K \Gamma}$ & EF & Kr & $\mathbf{E} \Gamma$ \\
\hline \multicolumn{9}{|c|}{ БЛОК I - Змістовий } \\
\hline 1 & $54,5 \%$ & $54,2 \%$ & $38,1 \%$ & $39,2 \%$ & $7,5 \%$ & $6,6 \%$ & 134 & 166 \\
\hline 2 & $41,8 \%$ & $39,2 \%$ & $31,3 \%$ & $28,9 \%$ & $26,9 \%$ & $31,9 \%$ & 134 & 166 \\
\hline 3 & $38,1 \%$ & $36,1 \%$ & $38,8 \%$ & $38,6 \%$ & $23,1 \%$ & $25,3 \%$ & 134 & 166 \\
\hline 4 & $66,4 \%$ & $66,9 \%$ & $0,0 \%$ & $0,0 \%$ & $33,6 \%$ & $33,1 \%$ & 134 & 166 \\
\hline $\begin{array}{c}\text { Середнс } \\
\text { за } \\
\text { блоком }\end{array}$ & $50,2 \%$ & $49,1 \%$ & $27,1 \%$ & $26,7 \%$ & $22,8 \%$ & $24,2 \%$ & 536 & 664 \\
\hline
\end{tabular}

3 поданої таблиці 2 видно, що у сформованості змістового компонента учнів на початку експерименту в обох групах (ЕГ, КГ) не має суттєвої різниці.

У контрольній (КГ) й експериментальній групвх (ЕГ) середнє відносне значення за змістовим блоком складає 50,2\% у КГ і 49,1\% у ЕГ при позитивних відповідях (так) щодо важливості здобувати знання з культурного різноманіття. Наразі значна перевага позитивних відповідей респондентів (більше 66\%) на запитання щодо необхідності самостійно дізнаватись про культури інших народів України і світу, свідчить про загальну мотивацію груп до отримання необхідних знань щодо культурного різноманіття. За іншими складовими (блоками) середнє значення за поведінковим при позитивних відповідях складає 53,7\% (КГ) і 50,7\% (ЕГ), що свідчить про незначну різницю підготовленості в обох групах. За блоком використання IКT-КОНС середнє значення при позитивних відповідях складає 60,9\% (КГ) і 60,8\% (ЕГ).

Після проведення навчально-виховних заходів з учнями ЗНЗ і семінарів у системі післядипломної педагогічної освіти було здійснено анкетування й подальше опрацювання результатів за обраними методиками - метод математичної статистики і метод кутового перетворення Фішера.

У кінці експерименту було отримано позитивну динаміку в обох групах учнів (КГ, ЕГ) і педагогів. Однак у експериментальній групі, яка проходила навчання, було відзначено значно вищий рівень сформованості полікультурної компетентності за блоками анкети. Розглянемо це детальніше.

Змістовий блок. Аналіз результатів формувального експерименту дозволив дійти такого висновку: на початок експерименту рівень підготовленості за змістовим блоком становив 50,2\% у КГ і 49,1\% у ЕГ, що свідчить про однаковий (середній) рівень сформованості, а на кінець експерименту у контрольній групі рівень сформованості полікультурної компетентності зріс до 61,4\%, а в експериментальної групи - до 80,3\%, що свідчить про високий рівень у ЕГ за визначеними критеріями. Загальна різниця між групами склала близько $31,2 \%$ (рис. 1). Це означає, що учні під час уроків і навчальновиховних заходів з культурного різноманіття отримали необхідні знання і навички. Динаміка змін змістового блоку на початок і кінець формувального експерименту між КГ та ЕГ представлена на рис. 1. 


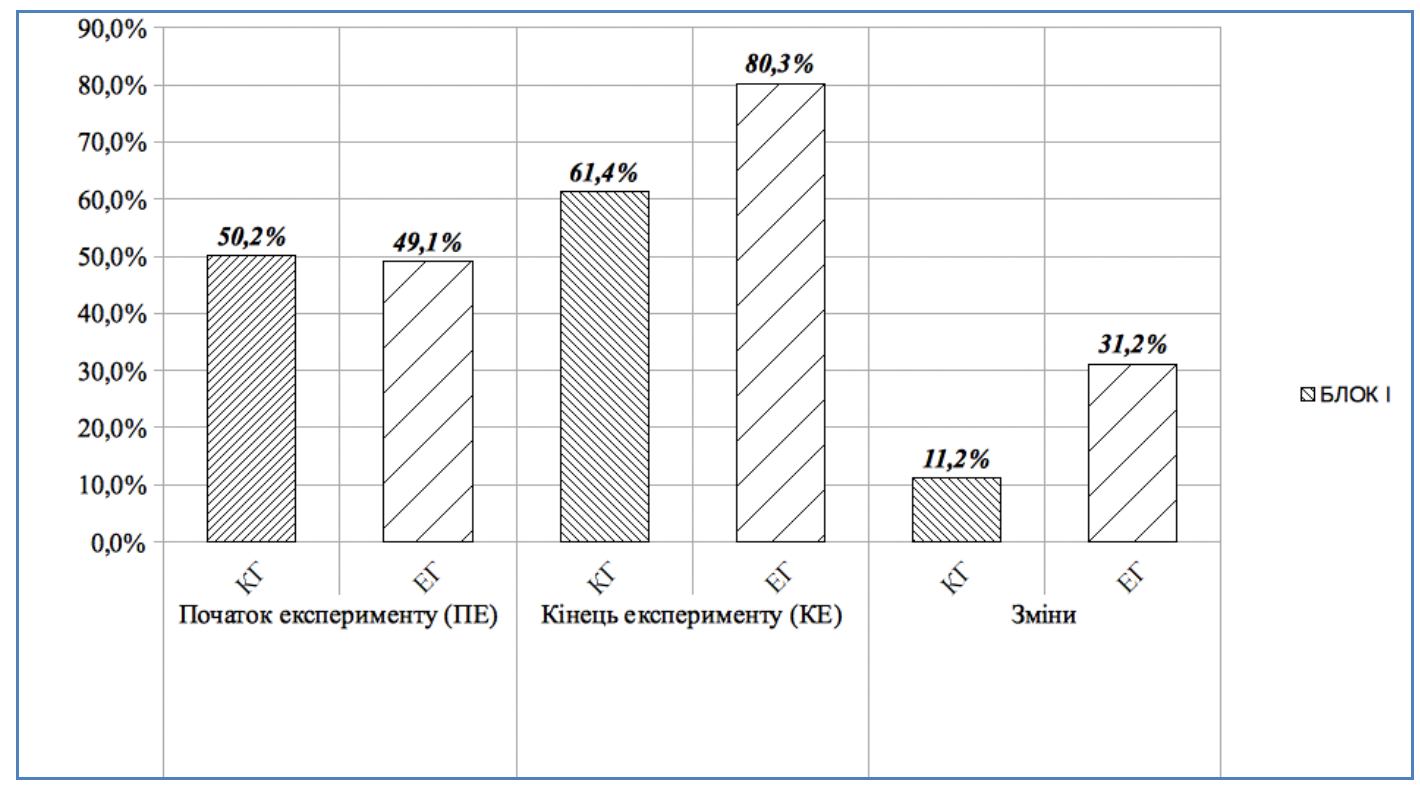

Рис. 1. Динаміка змін змістового блоку на початок і кінець формувального експерименту у КГ та ЕГ

Обрахування поведінкового блоку і блоку використання ІКТ-КОНС проводились аналогічно змістового.

Поведінковий блок. На початок експерименту рівень сформованості за поведінковим блоком складав 53,7\%, у КГ і 50,7\% у ЕГ, що свідчить про низький рівень сформованості полікультурної компетентності, а на кінець експерименту в контрольній групі рівень сформованості зріс до 57,8\%, а і експериментальній групі - до $81,8 \%$, що свідчить про те, що КГ досягла середнього рівня, а ЕГ - високого рівня за визначеними критеріями. Оскільки в ЕГ було створено необхідні умови для набуття учнями необхідних знань 3 питань прав людини, демократичного громадянства, подолання стереотипів щодо інших культур і націй, сформовано бажання спілкуватись і взаємодіяти з представниками інших культур, було відзначено значну різницю між групами. Величина змін у кожній групі складає: КГ - 4,1\%, ЕГ - 31, $2 \%$.

Динаміку змін щодо поведінкового блоку на початок і кінець формувального експерименту між КГ й ЕГ представлено на рис. 2.

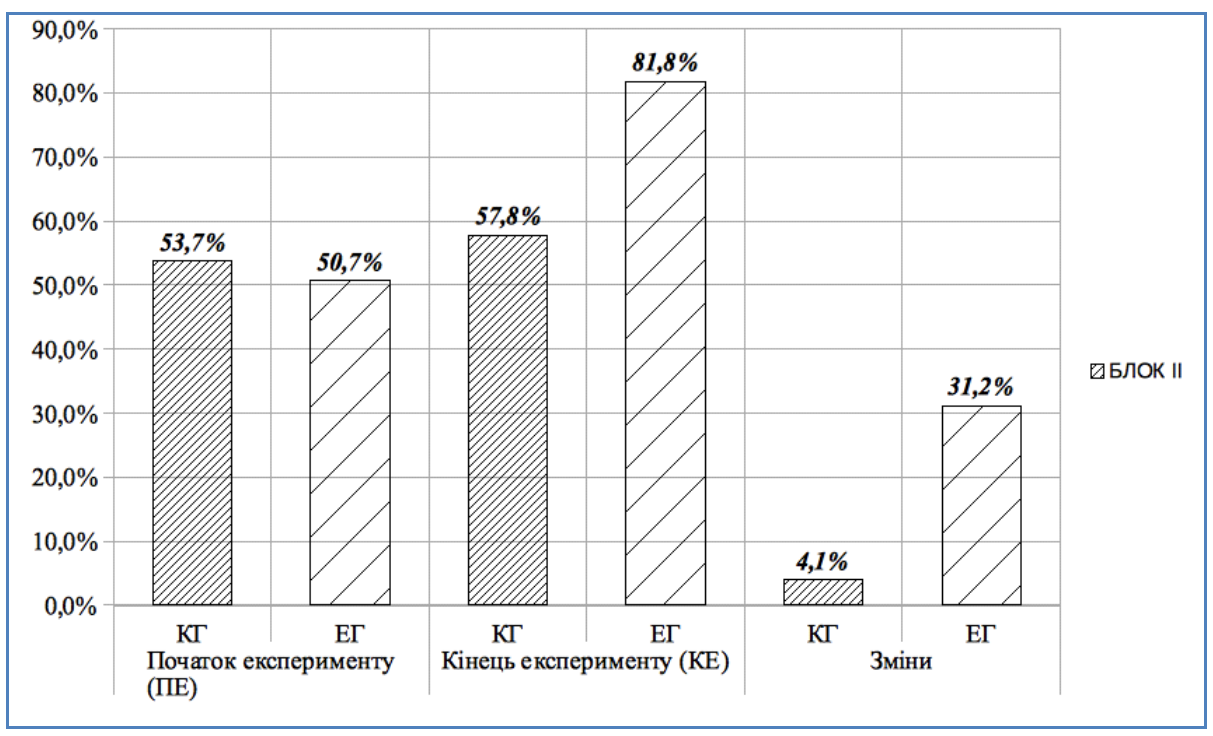


Рис. 2. Динаміка змін щуодо поведінкового блоку на початок $і$ кінещь формувального експерименту між КГ й ЕГ

Слід зазначити, що цілеспрямована діяльність учнів у рамках комп'ютерно орієнтованого навчального середовища, підтримка цього середовища з боку вчителя $\mathrm{i}$ створення сприятливих умов для його функціонування, мотивація та заохочення участі учнів i вчителів у педагогічно спрямованій діяльності стимулює зростання зацікавленості, розвиває полікультурну компетентність і навички роботи з IКТ, формує позитивне ставлення до різноманіття культур.

Блок використання ІКТ-КОНС. Аналіз результатів формувального експерименту дозволив зробити висновок: на початок експерименту рівень сформованості полікультурної компетентності за блоком використання IКТ-КОНС в КГ становив 60,9\%, в ЕГ 60,8\%, що складає середній рівень сформованості, а на кінець експерименту в КГ групи рівень сформованості за блоком IКТ-КОНС зріс до 66,1\%, а в ЕГ - до 83,3\% і досяг високого рівня. Величина змін у кожній групі складає: КГ - 5,1\%, $\mathrm{E} \Gamma-22,6 \%$.

Слід зазначити, що цей блок спрямовано, з одного боку, на створення на достатньому рівні в навчальному закладі умов технічного забезпечення i функціонування КОНС та участі в ньому учнів 8-9-х та 9-10-х класів, що складали КГ й ЕГ, a, з іншого, - на зацікавленість і бажання учнів використати всі умови КОНС для формування полікультурної компетентності, створення спільнот за інтересами i навчання. Саме тому важливою умовою виступає їх участь в освітніх спільнотах, які допомагають дізнатись про інші культури, використати свою обізнаність у сфері культурного різноманіття і виявити своє ставлення до цього.

Динаміку змін блоку використання ІКТ-КОНС на початок і кінець формувального експерименту в КГ й ЕГ представлено на рис. 3.

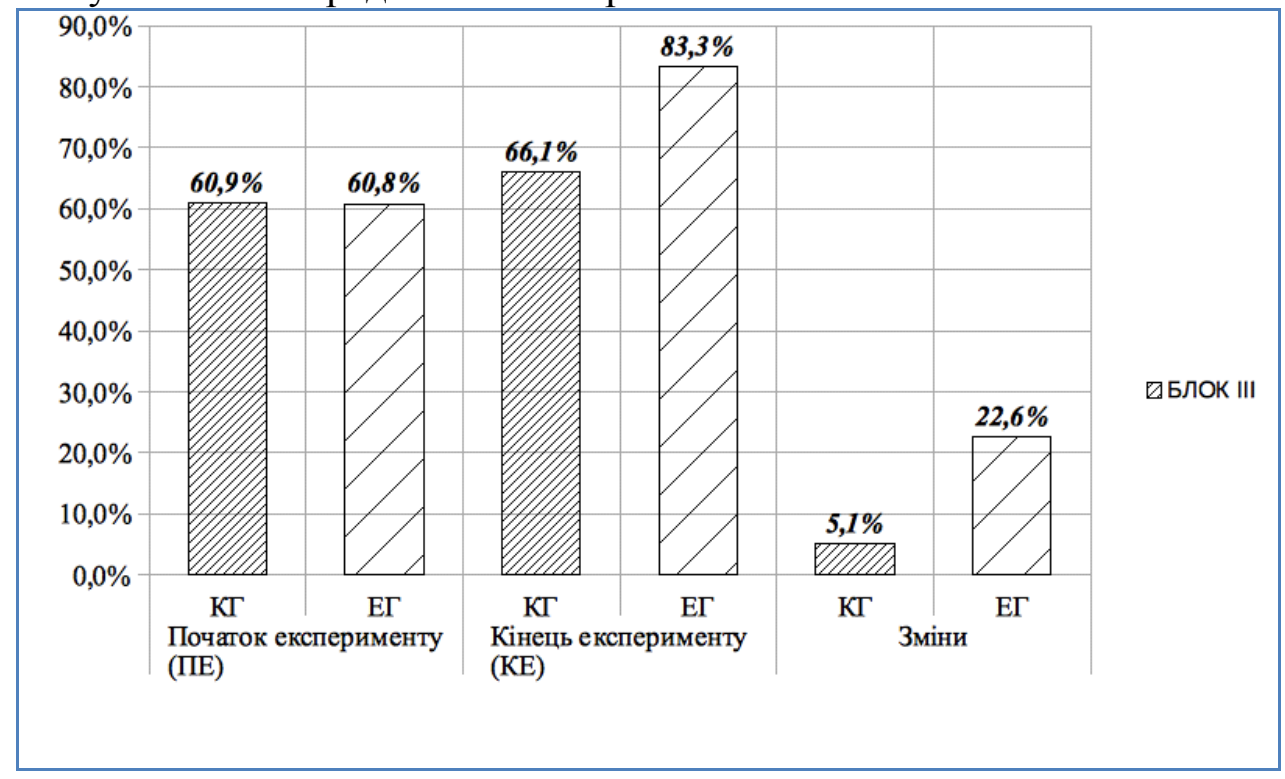

Рис. 3. Динаміка змін блоку ІКТ-КОНС на початок $і$ кінець формувального експерименту в КГ й ЕГ

Узагальнені результати за всіма блоками. Аналіз результатів формувального експерименту щодо всіх блоків, реалізація яких стала основною умовою підвищення рівня сформованості полікультурної компетентності дозволив зробити висновок: на початок експерименту сформованість полікультурної компетентності у КГ становила $56,3 \%$, а в ЕГ 54,9\%, що склала середній рівень. На кінець експерименту в КГ групи 
рівень сформованості збільшився до 62,2\%, що відповідає середньому рівню, а в ЕГ до 82,2 \%, що відповідає високому рівню підготовленості. Динаміка змін між рівнями сформованості полікультурної компетентності в ЕГ на 21,3\% вища, ніж у КГ.

Результати обох груп (ЕГ і КГ) за всіма блоками представлено на рис. 4.

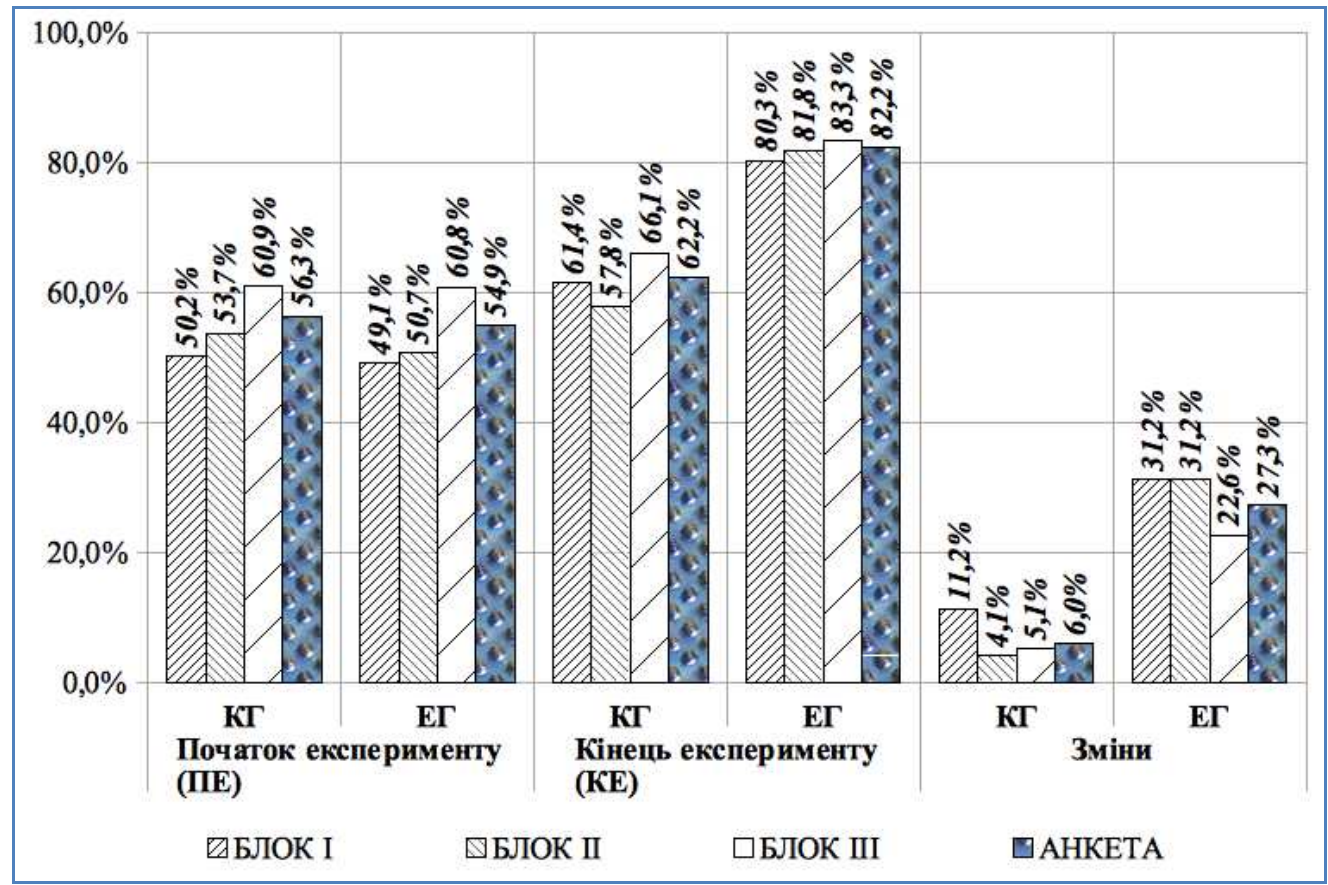

Рис. 4. Динаміка змін за результатами експерименту на початок $і$ кінець формувального експерименту в КГ й ЕГ

Аналіз змін у блоках, що стосувались рівня сформованості полікультурної компетентності, показав таке:

- за змістовим блоком на початок проведення експерименту рівень сформованості полікультурної компетентності учнів знаходився в КГ і в ЕГ на середньому рівні, а на кінець експерименту рівень сформованості в ЕГ збільшився до високого рівня, а в КГ підвищився у межах середнього рівня;

- за поведінковим блоком на початок експерименту сформованість полікультурної компетентності знаходилась у КГ на межі низького i середнього рівнів, а в ЕГ на середньому, а на кінець експерименту в КГ сформованість збільшилась у межах середнього рівня, а в ЕГ - до межі високого рівня;

- за блоком використання IКТ-КОНС у КГ і ЕГ сформованість полікультурної компетентності знаходилась на початок експерименту на середньому рівні; а на кінець експерименту сформованість у КГ підвищилась в межах середнього рівня, а в ЕГ - досягла високого рівня.

У середньому за результатами експерименту відзначено те, що в контрольній групі відбулись позитивні зміни в межах середнього рівня внаслідок самостійного опанування матеріалами, які надавав учитель у межах стандартної навчальної програми. У експериментальній групі відбулись значні зміни із середнього до високого рівня сформованості полікультурної компетентності внаслідок проведення уроків і заходів за методичними рекомендаціями «Використання електронних освітніх ресурсів комп'ютерно орієнтованого навчального середовища в умовах полікультурної освіти учнів» і створення необхідних умов у загальноосвітньому навчальному закладі. 


\section{4. ВИСНОВКИ ТА ПЕРСПЕКТИВИ ПОДАЛЬШИХ ДОСЛІДЖЕНЬ}

Проведений педагогічний експеримент підтвердив робочу гіпотезу дослідження: підвищення рівня сформованості полікультурної компетентності учнів у комп'ютерно орієнтованому навчальному середовищі може бути досягнуто через педагогічно доцільне і науково-обгрунтоване застосування змісту, форм та засобів комп'ютерно орієнтованого навчального середовища в умовах полікультурної освіти в навчальновиховному процесі.

Перспективою подальших досліджень $є$ створення програм дистанційного навчання з полікультурної освіти; вивчення досвіду країн зарубіжжя з використання IКТ у здійсненні учнівських проектів 3 питань громадянської освіти; підготовка та підвищення кваліфікації вчителів 3 питань використання КОНС в умовах полікультурної освіти.

\section{СПИСОК ВИКОРИСТАНИХ ДЖЕРЕЛ}

1. Іванюк І. В. Модель комп'ютерно орієнтованого навчального середовища розвитку полікультурної компетентності учнів [Електронний ресурс] / I. В. Іванюк // Інформаційні технології і засоби навчання: електронне наукове фахове видання. - Електронні дані. - [Ін-т. інформ. технологій і засобів навчання АПН країни, Центр. ін-т післядипл. освіти. АПН України, 2015]. - №6. - Режим доступу : http://journal.iitta.gov.ua/index.php/itlt/article/view/1319/996. - Назва з екрану.

2. Thomas A. Intercultural competence: Princilpes, problems, concepts / A. Thomas // Erwagen, Wissen, Ehik. - 2003. - Vol.14 (1). - P. 137150.

3. Interkulturekke Kompetenz. IKUD Seminare [Електронний pecypc] [зб.наук.мат. 3 питань полікультурної компетентності Інституту інтеркультурної дидактики, Німеччина] - Електронні дані. - 2011. - Режим доступу : http://www.ikud-seminare.de/interkulturelle-kompetenz.html. - Назва 3 екрану.

4. Гончаренко Л. А. Формування полікультурної компетентності вчителів загальноосвітньої школи: навчальний посібник для студентів / Л. А. Гончаренко, В. В. Кузьменко. - Х.: РІПО, 2006. - 92 с.

5. Воротняк Л. І. Особливості формування полікультурної компетенції магістрів у вищих педагогічних навчальних закладах / Л. І. Воротняк // Вісник Житомирського державного університету (Педагогічні науки). - 2008. - № 39. - С. 105-109.

6. Сімоненко М. В. Полікультурна компетентність майбутнього вчителя як стандарт освіти європейського виміру [Електронний ресурс] / Сімоненко М.В. // - Електронні дані. Педагогические науки. - 2010 - №2. - Режим доступу: http://www.rusnauka.com/6_NITSB_2010/Pedagogica/58322.doc.htm. - Назва з екрану.

7. Сисоєва С. О. Проблеми дистанційного навчання: педагогічний аспект / С. О. Сисоєва // Неперервна професійна освіта- 2003. - Вип. 3-4.- С. 78-87.

8. Жук Ю. О. Особистісний простір учня в комп'ютерно-орієнтованому навчальному середовищі [Електронний ресурс] / Ю. О. Жук // Інформаційні технології і засоби навчання: електронне наукове фахове видання. - Електронні дані. - [Ін-т. інформ. технологій і засобів навчання АПН країни, Центр. ін-т післядипл. освіти. АПН України, 2012]. - №3(29). - Режим доступу : http://journal.iitta.gov.ua/index.php/ittl/article/view/693/508. - Назва з екрану.

9. Биков В. Ю. Моделі організаційних систем відкритої освіти: монографія / В. Ю. Биков. - К. : Атіка, 2008. - 684 c.

10. Гончаренко С. У. Педагогічні дослідження: методологічні поради молодим науковцям/ С. У. Гончаренко. - К.: АПН України, 1995. - 45 с.

11. Іванюк I. В. Використання електронних освітніх ресурсів комп'ютерно орієнтованого навчального середовища в умовах полікультурної освіти учнів: методичні рекомендації / I. В. Іванюк. Дрогобич : Видавничій відділ ДДПУ імені І. Франка, 2016. - 60 с.

12. Гершунский Б. С. Прогнозирование содержания обучения в технікумах : учебно - методическое пособие / Б. С. Гершунский. - М. : Высшая школа, 1980. - 144 с.

13. Сидоренко Е. В. Методы математической обработки в психологии / Е. В. Сидоренко. - СПб.: ООО «Речь», 2001. - 350 c.

14. Фишер Р. А. Статистические методы для исследователей / Р. А. Фишер. - М. : Госстатиздат, 1958. $-267 \mathrm{c}$. 
15. Olson C. L., Kroeger K. R. Global competency and intercultural sensitivity / C. L. Olson, K. R. Kroeger // Journal of Studies in International Education. - 2001. - № 5. - Pp. 116-137.

16. Samardžić-Marković Snežana. Pioneering work on democratic competences to transform the way we live and work [Електронний ресурс] / S. Samardžić-Marković // - New Europe. - 2015. - Електронні дані. - Режим доступу : http://neurope.eu/article/pioneering-work-democratic-competences-transform-waywe-live-and-work/. - Назва з екрану.

Матеріал надійшов до редакиї 22.01.2016 p.

\title{
ПЕДАГОГИЧЕСКИЙ ЭКСПЕРИМЕНТ УРОВНЯ СФОРМИРОВАННОЙ ПОЛИКУЛЬТУРНОЙ КОМПЕТЕНТНОСТИ УЧЕНИКА В УСЛОВИЯХ КОМПЬЮТЕРНО ОРИЕНТИРОВАННОЙ УЧЕБНОЙ СРЕДЫ
}

\author{
Иванюк Ирина Владимировна \\ научный сотрудник отдела компаративистики информационно-образовательных инноваций \\ Институт информационных технологий и средств обучения НАПН Украины, г. Киев, Украина \\ iivanyuk@yandex.ru
}

\begin{abstract}
Аннотация. В статье представлены результаты экспериментальной проверки уровней сформированной поликультурной компетентности учащихся общеобразовательных учебных заведений в условиях компьютерно ориентированной учебной среды. Определены критерии оценки уровня сформированной поликультурной компетентности учащихся. Сделан вывод, что проведенный педагогический эксперимент подтвердил рабочую гипотезу исследования: повышение уровня сформированной поликультурной компетентности учащихся в компьютерно ориентированной учебной среде может быть достигнуто через педагогически целесообразное и научно-обоснованное применение содержания, форм и средств компьютерно ориентированной учебной среды в условиях поликультурного образования в учебно-воспитательном процессе.
\end{abstract}

Ключевые слова: поликультурная компетентность; компьютерно ориентированная учебная среда; педагогический эксперимент.

\section{PEDAGOGICAL EXPERIMENT ON FORMATION OF STUDENT MULTICULTURAL COMPETENCY UNDER CONDITIONS OF COMPUTER- ORIENTED LEARNING ENVIRONMENT}

\section{Iryna V. Ivanyuk}

Researcher, Comparative Studies Department for Information and Education Innovations Institute of Information Technologies and Learning Tools of NAES of Ukraine, Kyiv, Ukraine iivanyuk@yandex.ru

\begin{abstract}
The article presents the results of experimental verification of the levels of multicultural competency of students in terms of computer-oriented learning environment. Pedagogical experiment is held by the author in the research "Development of computer-oriented learning environment in the term of multicultural education students in the European Union." It was found the content of "multicultural competency of students" and clarified the basic content of the study "computer-oriented learning environment in terms of multicultural education of pupils." A scientific theories, approaches and principles for the formation of multicultural competence of students in terms of computer-based learning environment identified. Described criteria for evaluation of multicultural competency levels of students in computer-oriented learning environment. It is concluded that the pedagogic al experiment confirmed the working hypothesis of the study: raising the level of multicultural competency formation of students in computeroriented learning environment can be achieved through pedagogically effective and scientifically justified use of content, form and means of computer-oriented learning environment in multicultural education in the educational process.
\end{abstract}


Keywords: multicultural competency; computer-oriented learning environment; pedagogical experiment.

\section{REFERENCES (TRANSLATED AND TRANSLITERATED)}

1. Ivaniuk I. V. Model of computer-oriented learning environment for the formation of multicultural competence of student environment [online] / I. V. Ivaniuk // Information technologies and means of teaching. - $\quad 2015$. $\quad-\quad № 6 . \quad-\quad$ Available from: http://journal.iitta.gov.ua/index.php/itlt/article/view/1319/996 (in Ukrainian)

2. Thomas A. Intercultural competence: Princilpes, problems, concepts / A. Thomas // Erwagen, Wissen, Ethik. - 2003. - Vol. 14 (1). - P. 137 - 150. (in English)

3. Interkulturekke Kompetenz. IKUD Seminare - 2011 - [online]. - Available from: http://www.ikud-seminare.de/interkulturelle-kompetenz.html (in German)

4. Goncharenko L. A. Formation of multicultural competence of secondary school teachers: a manual for students / L. A. Goncharenko, V. V. Kuzmenko. - H.: RIPO, 2006. - 92 p. (in Ukrainian)

5. Vorotniak L. I. Features of formation of Masters multicultural competence in higher educational institutions / L. I. Vorotniak // Bulletin Zhytomyr State University (Pedagogical Sciences). - 2008. - № 39. - P. 105-109. (in Ukrainian)

6. Simonenko M. V. Multicultural competence of future teacher as a standard European dimension of education [online] / M. V. Simonenko // Pedagogical Sciences. - 2010 - №2. - Available from: http://www.rusnauka.com/6_NITSB_2010 (in Ukrainian)

7. Sysoeva S. O. Problems of distance education: pedagogical aspect / S. O. Sysoeva // Lifelong learning professional education. - 2003 - Vol. 3-4. - P. 78-87. (in Ukrainian)

8. Zhuk Y. O. The personal space of student in computer-oriented learning environment [online] / Y. A. Zhuk // Information technologies and means of teaching. - 2012. - №3 (29). - Available from: http://journal.iitta.gov.ua/index.php/ittt/article/view/693/508 (in Ukrainian)

9. Bykov V. Y. Organizational models of open education: monograph / V. Y. Bykov. - K.: Atika, 2008. - 684 p. (in Ukrainian)

10. Goncharenko S. U. Teaching research: methodological advice to young scientists / S. U. Goncharenko. - K.: APS of Ukraine, 1995. - 45 p. (in Ukrainian)

11. Ivaniuk I. V. The use of electronic educational resources of computer-based learning environment in multicultural education students: guidelines / I. V. Ivaniuk - Drohobych: Publications Department DDPU Franko, 2016. - 60 p. (in Ukrainian)

12. Gershunsky B. S. Prediction of teaching content in technical schools: manual / B. S. Gershunskyy - M .: Higher School, 1980. - 144 p. (in Russian)

13. Sidorenko E. V. Mathematical processing methods in psychology / E. V. Sidorenko. - St. Petersburg: OOO "Rech", 2001. - 350 p. (in Russian)

14. Fisher R. A. Statistical methods for researchers / R. A. Fisher. - M.: Gosstatizdat, 1958. - 267 p. (in Russian)

15. Olson C. L., Kroeger K. R. Global competency and intercultural sensitivity / C. L. Olson, K. R. Kroeger // Journal of Studies in International Education. - 2001. - № 5. - pp. 116-137. (in English)

16. Samardžić-Marković Snežana. Pioneering work on democratic competences to transform the way we live and work [online]. / S. Samardžić-Marković // New Europe. - 2015. - Available from : http://neurope.eu/article/pioneering-work-democratic-competences-transform-way-we-live-andwork/ (in English)

Conflict of interest. The author has declared no conflict of interest.

\section{$(\mathrm{Cc}) \mathrm{BY}-\mathrm{NC}-\mathrm{SA}$}

This work is licensed under Creative Commons Attribution-NonCommercial-ShareAlike 4.0 International License. 